\title{
Mycorrhizal inoculation of micropropagated woody legumes used in revegetation programmes for desertified Mediterranean ecosystems
}

\author{
CP Salamanca, MA Herrera, JM Barea * \\ CSIC, Estación Experimental del Zaidín, Departamento de Microbiología, Prof Albareda 1, \\ 18008 Granada, Spain
}

(COST Meeting, 21-23 May 1992, Dijon, France)

\begin{abstract}
Summary - Micropropagation of Anthyllis cytisoides (L) and Spartium junceum (L) 2 shrub legumes of ecological interest, was accomplished following standard procedures. Inoculation with the arbuscular mycorrhizal fungus Glomus fasciculatum, early during a post vitro weaning stage shortened the acclimatization process by 8 wk and particularly for Anthyllis improved survival, growth and nutrient status of microplants after outplanting. The level of mycorrhizal colonization of microplants was about the same as that for plants produced from seeds.
\end{abstract}

micropropagation / Glomus fasciculatum / Anthyllis / Spartium / desertification

Résumé - Inoculation mycorhizienne de légumineuses ligneuses micropropagées utilisées dans les programmes de remise en végétation des écosystèmes desertifiés méditerranéens. La micropropagation d'Anthyllis cytisoides $L$, et de Spartium junceum $L 2$ légumineuses intéressantes du point de vue écologique a été réalisée suivant des techniques usuelles. L'inoculation avec Glomus fasciculatum tôt pendant le sevrage post vitro raccourcit l'acclimatation de 8 semaines, et en particulier pour Anthyllis, améliore la survie, la croissance et la nutrition des microplantes après leur plantation au dehors. Le niveau de mycorhization était à peu près le même que pour des plantes issues de semis.

micropropagation / Glomus fasciculatum / Anthyllis / Spartium / désertification

\section{INTRODUCTION}

Micropropagation techniques have been recently applied for clonal selection and mass production of mycotrophic (arbuscular mycorrhizal) woody species of ecological interest. The available information mainly concerns tree species and reafforestation programmes in Mediterranean ecosystems (Morte et al, 1992; Nouaim et al, 1992). In this ecological context, and since it has been found that for some desertified semi-arid areas it would be more appropriate to develop shrublands rather than attempt afforestation (Francis and Thornes, 1990), production of plant material of the appropriate shrubs species to be used in revegetation has become critical. As far as we know there is no published information regarding micropropagation of shrubs of interest to recover degraded lands.
Previous studies have shown that 2 native shrub legumes, Anthyllis cytisoides (L) and Spartium junceum $(L)$, could be good candidate species for a reclamation strategy in the Mediterranean region (Barea et al, 1990b). Mycorrhizal inoculation with Glomales fungi has been found highly effective in improving plant establishment and survival. Seeds of these plant species are not commercially available so that only fieldgrown individuals with recognized ecological value can be used as a seed source. Micropropagation therefore constitutes a promising technique for mass production. The aim of the present study was to develop in vitro propagation of these 2 species and to ascertain whether an effective mycorrhizal symbiosis could be obtained in rooted micropropagated plantlets by inoculation with appropriate arbuscular mycorrhizal (AM) fungi early on during a post vitro weaning stage. 


\section{MATERIAL AND METHODS}

\section{Plant material and culture conditions}

Anthyllis cytisoides (L) and Spartium junceum (L) are 2 shrub legumes that form part of the natural succession in southern Spain, and that are useful for land restoration (Barea et al, 1990b; Francis and Thornes, 1990). Seeds of these plant species were germinated on moistened sand and then grown on a soil-sand mixture in a greenhouse (Barea et al, 1990a).

\section{Micropropagation of host plants}

Axillary buds $\approx 0.3 \mathrm{~cm}$ long were excised from appropriate seedlings. These initial explants were surface disinfected (Morte et al, 1992) and then transferred to the basal medium of Murashige and Skoog (1962), supplemented with 6-benzyladenine (BA) $\left(0.2 \mathrm{mg} . \mathrm{l}^{-1}\right)$ or indole-3-butyric acid (IBA) $\left(0.1 \mathrm{mg} . \mathrm{I}^{-1}\right)$. The $\mathrm{pH}$ was adjusted to 5.7 before autoclaving. Cultures were grown at $25^{\circ} \mathrm{C}$ with a 16-h photoperiod (Sylvania GroLux fluorescent lamps) which provided a photosynthetic photon flux (PPF) of $45 \mu \mathrm{E} . \mathrm{s}^{-1} \cdot \mathrm{m}^{-2}$. After 4 weeks' culture, shoots with visible roots were transferred to sealed glass flasks $(500 \mathrm{ml})$ containing 200 $\mathrm{ml}$ peat-perlite medium (1:1 v/v) (Vidal et al, 1992). Four plantlets per flask were kept in a greenhouse for 4 or 6 wk. As indicated in figure 1, different acclimatization procedures and schedules were compared for AM inoculated plantlets and non inoculated controls.

\section{Mycorrhizal inoculum}

Glomus fasciculatum (Thaxter sensu Gerd) Gerd and Trappe was chosen among various $A M$ fungal isolates after a previous selection for functional compatibility with the micropropagated plant species (Barea et al, $1990 \mathrm{~b})$. The inoculum consisted of washed mycorrhizal roots with the external mycelium and spores attached, but free from soil particles. Inoculum (1 g fresh weight) cut into $1-\mathrm{cm}$ fragments was applied to each plantlet close to the root system. As figure 1 indicates, the rooted plantlets were inoculated when transferred from the flask to $250-\mathrm{ml}$ pots. The potting medium consisted of a soil-sand mixture $(5: 2, \mathrm{v} / \mathrm{v})$. Plants were transferred to a greenhouse and gradually exposed to reduced relative humidity by progressively removing a plastic cover during a $1-2$-wk period. The non inoculated plants treated in the same way quickly died and were therefore kept for a further period of 6 wk in a misting tunnel before being transferred to the greenhouse.

\section{Growth conditions}

Inoculated and non-inoculated (control) plants (20 replicated per treatment) were grown in a greenhouse under controlled conditions with day-night temperatures ranging from $19-25^{\circ} \mathrm{C}$. Daylength was extended to $16 \mathrm{~h}$ by cool white fluorescent lamps, providing a PPF of $650 \mu \mathrm{E} . \mathrm{s}^{-1} \cdot \mathrm{m}^{-2}$. Plantlets were fertilized weekly with $10 \mathrm{ml}$ full strength Long Ashton nutrient solution (Hewitt, 1952) and watered daily. Percent survival, dry matter yield, $P$ concentration in plant shoots and the degree of mycorrhizal colonization were recorded after an additional 2-wk growing period in an open greenhouse (Vidal et al, 1992).

Student's t-test was used for statistical analysis of data. In the case of the values given as percentages, data were subjected to an arcsin square-root transformation to ensure homogeneity of variances.

\section{RESULTS}

The micropropagation procedure used resulted in a $60 \%$ rooting rate. Five subcultures from the initial stock still yielded suitable plant material. As figure 1 indicates, inoculation with the arbuscular mycorrhizal fungus Glomus fasciculatum early on during the post vitro weaning shortened the acclimatization process by $8 \mathrm{wk}$.

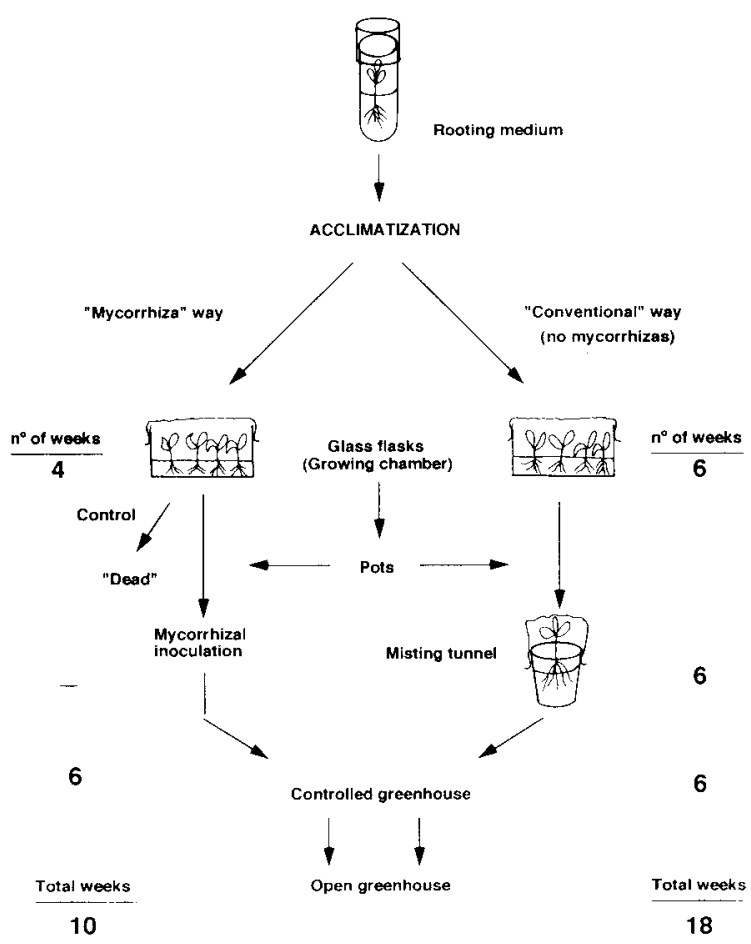

Fig 1. Acclimatization procedure and schedule. 
Data summarized in figure 2 show that the survival of microplants after outplanting was generally good but $A M$ inoculation still improved outplanting performance in Anthyllis. Growth, P concentration and content in this species were also significantly improved by mycorrhizal inoculation (fig 2). The degree of mycorrhizal colonization developing in roots of the vitroplants was
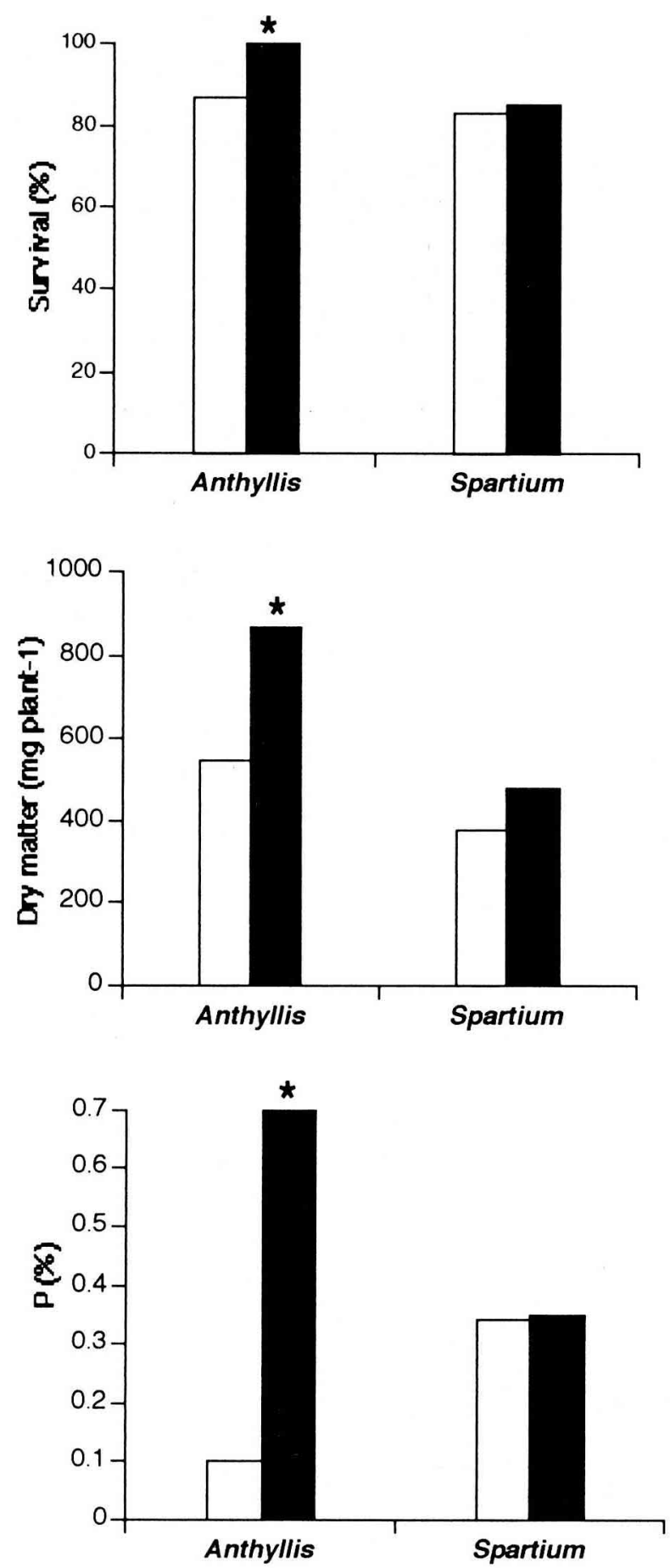

Fig 2. Effect of Glomus fasciculatum on survival, growth and nutrient status of microplants of Anthyllis and Spartium. Mycorrhizal plants (四) were 12-wk old, and non mycorrhizal ones (1) 20 wk old. * Significant effects at the $5 \%$ level.

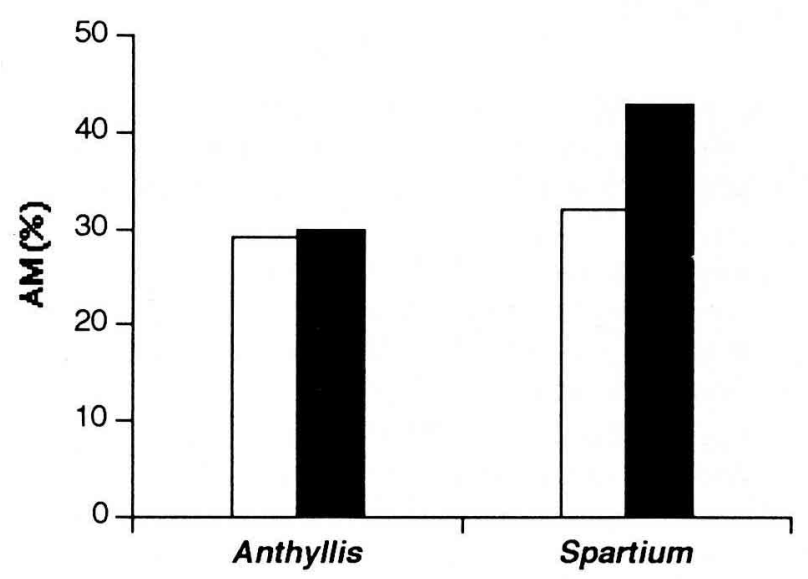

Fig 3. Comparison of the mycorrhizal colonization (percent) $(\mathrm{AM} \%)$ of microplants (Ј), and plantlets of the same age grown from seeds $(\square)$.

about the same as for plantlets of the same age but propagated from seeds (fig 3 ).

\section{DISCUSSION}

It is obvious that inoculation of Anthyllis microplants with the AM fungus Glomus fasciculatum early on during a post vitro weaning stage improved plant growth and nutrition. However, the most noticeable effect of $A M$ inoculation which also applied to the other shrub legume, ie Spartium, was the shortening of the acclimatization process (fig 1). This is an important factor in micropropagation (Ravolanirina et al, 1989). Since the ideal situation is to induce mycorrhizal status as early as possible during the micropropagation schedule (Gianinazzi et al, 1990), AM inoculation was also attempted directly in vitro after transfer to the flask stage (fig 1). Although mycorrhizal establishment was obtained in a few cases with concomitant plantlet growth improvement, the percentage of microplant survival was in fact very low, as was the level of mycorrhizal establishment. Work is now in progress to test different inoculum formulations and substrate combinations in order to improve AM colonization at the flask stage.

\section{ACKNOWLEDGMENT}

This study was supported by CICYT Spain (Project No NAT91-1127). 


\section{REFERENCES}

Azcon R, Barea JM (1982) Nodulation, $\mathrm{N}_{2}$ fixation $\left({ }^{15} \mathrm{~N}\right)$ and $\mathrm{N}$ nutrition relationships in mycorrhizal or phosphate amended alfalfa plants. Symbiosis 12 , 33-41

Barea JM, Azcón R, Azcón-Aguilar C (1992) Vesicular-arbuscular mycorrhizal fungi in nitrogen-fixing systems. In: Methods in Microbiology (Reid V, ed) Academic Press, London, 392-416

Barea JM, Salamanca CP, Herrera MA (1990a) The role of VA-mycorrhiza at improving $\mathrm{N}_{2}$-fixation by woody legumes in arid zones. In: Fast Growing Trees and Nitrogen Fixing Trees (Werner D, Müller $P$, eds) Gustav Fischer, Stuttgart, 303-311

Barea JM, Salamanca $C P$, Herrera MA, RoldánFajardo BE (1990b) Microorganisms-plant symbioses in the establishment of a vegetal cover on degraded lands. In: Soil Degradation and Rehabilitation in Mediterranean Environmental Conditions (Albaladejo J, Stocking MA, Díaz E, eds) Consejo Superior de Investigaciones Científicas, Murcia, Spain, 139-158

Francis CF, Thornes JB (1990) Matorral: erosion and reclamation. In: Soil Degradation and Rehabilitation in Mediterranean Environmental Conditions (Albaladejo J, Stocking MA, Díaz E, eds) Consejo Superior de Investigaciones Científicas, Murcia, Spain, 87-116
Gianinazzi S, Gianinazzi-Pearson V, Trouvelot A (1990) Potentialities and procedures for the use of endomycorrhizas with special emphasis on high value crops. In: Biotechnology of Fungi for Improving Plant Growth (Whipps JM, Lumsden B, eds) University Press, Cambridge, UK, 41-54

Hewitt EJ (1952) Sand and Water Culture Methods Used in the Study of Plant Nutrition (Farnham R, ed) Commonw Agric Bur, Tech Commun, 22

Morte MA, Honrubia M, Piqueras A (1992) Micropropagation of Tetraclinis articulata (Vahl) Masters (Cupressaceae). Plant Cell Tissue Organ Cult 28, 231233

Murashige T, Shoog $F$ (1962) A reviewed medium for rapid growth and bioassays with tobacco tissue cultures. Physiol Plant 15, 463-497

Nouaim R, Mangin G, Chaussod R (1992) In vitro propagation of the argan tree (Argania spinosa) and VA mycorrhization micropropagation. Root Regen Mycorrhizas Joint Meet COST-87, 810. Dijon, May 1992

Ravolanirina F, Blai B, Gianinazzi S, GianinazziPearson V (1989) Mise au point d'une méthode rapid d'endomycorhization de vitro-plants. Fruits 44, 165-170

Vidal MT, Azcón-Aguilar C, Barea JM, Pliego-Alfaro F (1992) Mycorrhizal inoculation enhances growth and development of micropropagated plants of avocado. HortSci 27, 785-787 